\title{
PERBANDINGAN EFEK KERJA MINUMAN BEROKSIGEN DAN AIR MINERAL TERHADAP SATURASI OKSIGEN DALAM DARAH SETELAH MELAKUKAN JOGING 30 MENIT TIM FUTSAL SMA ISLAM AL MARUF JAKARTA TIMUR
}

\author{
Bean Ken Giatarma ${ }^{1}$, \\ Yasep Setiakarnawijaya ${ }^{2}$, Hendro Wardoyo ${ }^{2}$ \\ ${ }^{2}$ Fakultas Ilmu Keolahragaan Universitas Negeri Jakarta, Kampus B, Jakarta
}

\begin{abstract}
Abstrak: Penelitian ini bertujuan untuk mengetahui 1). Efek kerja minuman beroksigen terhadap saturasi oksigen dalam darah setelah melakukan aktifitas jogging selama 30 menit. 2). Efek kerja minuman air mineral (aqua) terhadap saturasi oksigen dalam darah setelah melakukan aktifitas jogging 30 menit. 3). Perbandingan minuman beroksigen dan air mineral terhadap saturasi oksigen dalam darah setelah melakukan aktifitas jogging 30 menit.Penelitian dilaksanakan pada bulan Juni 2015. metode yang digunakan adalah metode eksperimen yaitu dengan pre-test sebelum melakukan dan post test setelah melakukan dan dengan teknik pengambilan purposive sampling, sampel yang berjumlah 10 dengan populasi 15 orang.Instrumen penelitian dengan teknik pengumpulan data yang akan digunakan dalam penelitian ini adalah variabel-variabel yang terdapat dalam peneliti dan diambil dengan pemberian tes sebelum perlakuan dan tes setelah perlakuan. Pada hasil penelitian perbandingan air beroksigen dan air mineral menghasilkan Efek kerja minuman beroksigen terhadap kadar oksigen dalam darah selah melakukan jogging 30 menit jadi Nilai t-tabel dengan derajat kebebasan (dk) $\mathrm{n}_{1}-1=10-1=9$ Pada taraf kepercayaan $\alpha=$ 0,05 adalah 2,26. Karena t-hitung $(8,5)>$ t-tabel $(2,26)$ maka hipotesa nihilnya ditolak Sehingga dapat disimpulkan bahwa terdapat efek kerja minuman beroksigen terhadap saturasi oksigen setelah jogging 30 menit. Efek kerja minuman air mineral terhadap kadar oksigen dalam darah setelah melakukan jogging 30 menit Nilai t-tabel dengan derajat kebebasan (dk) $n_{1}-$ $1=10-1=9$ Pada taraf kepercayaan $\alpha=0,05$ adalah 2,26. Karena t-hitung (1) < t-tabel $(2,26)$ maka hipotesa nihilnya diterima Sehingga dapat disimpulkan bahwa efek kerja air mineral terhadap saturasi oksigen setelah jogging 30 menit tidak terdapat perbedaan. Perbandingan air minum beroksigen dan air mineral terhadap saturasi oksigen dalam darah setelah melakukan jogging terdapat perbedaan pada hasil tes, yang menunjukan air beroksigen lebih signifikan. Karena t-hitung $(2,90)>t$-tabel $(2,10)$, dengan demikian Hipotesa nihilnya ditolak, ada perbedaan pengaruh peningkatan kadar oksigen dalam darah pada air minum beroksigen dan air mineral dimana air beroksigen mendapat pengaruh lebih besar terhadap peningkatan kadar oksigen dalam darah dibandingkan dengan air mineral setelah melakukan jogging selama 30 menit. Maka diambil keputusan bahwa terdapat penigkatan kadar oksigen dalam darah pada air beroksigen dan efek kerja minuman beroksigen lebih signifikan hasilnya.
\end{abstract}

Kata Kunci: Minuman Beroksigen, Air Mineral 


\section{PENDAHULUAN}

Olahraga mempunyai peranan penting bagi kesehatan tubuh maupun organ tubuh manusia lainnya.dengan berolahraga maka kita dapat mengetahui kondisi fisik kita, selain berolahraga tubuh kita perlu asupan makanan dan minuman agar tetap terjaga kesehatan tubuh, dalam ilmu kesehatan setiap sel membutuhkan oksigen untuk mengubah energi makanan menjadi ATP (Adenosine Triphosphate) yang siap pakai untuk kerja tiap sel yang paling sedikit mengkonsumsi oksigen adalah otot dalam keadaan istrahat.Sel otot yang berkontraksi membutuhkan banyak ATP. Akibatnya otot yang dipakai dalam latihan membutuhkan lebih banyak oksigen. Sel otot membutuhkan banyak oksigen untuk melakukan aktifitas terutama dalam kegiatan berolahraga. orang yang rutin berolahraga lebih jarang mengalami kelelahan aktifitas hariannya karena olahraga merupakan pembangit energi yang alami bagi tubuh kita.

Salah satu kebutuhan yang terpenting dalam tubuh manusia adalah Kebutuhan akan Oksigen, kebutuhan tersebut dapat diukur melalui pernafasan kita. Tingkat Kebugaran dapat diukur dari volume Anda dalam mengkonsumsi oksigen saat latihan pada volume dan kapasitas maksimum.kelelahan biasanya salah satu masalah yang dihadapi saat sehabis olahraga, Kelelahan seseorang yang dirasakan akan menyebabkan turunnya konsentrasi sehingga tanpa konsentrasi yang prima terhadap suatu permainan, sudah hampir dipastikan kegagalan yang akan diterima. Cepat atau lambatnya kelelahan oleh seseorang dapat diperkirakan dari kapasitas aerobik atlet yang kurang baik. Kapasitas aerobik menunjukkan kapasitas maksimal oksigen yang dipergunakan oleh tubuh (VO2Max). oleh karna itu oksigen berperan penting dalam kegiatan sehari-hari kita terlebih saat berolahraga. Seperti yang kita ketahui bersama oksigen merupakan bahan bakar tubuh kita. Oksigen dibutuhkan oleh otot dalam melakukan setiap aktivitas berat maupun ringan. Dan semakin banyak oksigen yang diasup/ diserap oleh tubuh menunjukkan semakin baik kinerja otot dalam bekerja sehingga zat sisa-sisa yang menyebabkan kelelahan jumlahnya akan semakin berkurang.

Dalam dunia olahraga air minum sangat dibutuhkan untuk kita konsumsi setelah berolahraga karena untuk menggantikan cairan yang keluar dari tubuh kita setelah beraktifitas fisik dan sejalan dengan modernisasi, perkembangan dunia teknologi di Indonesia sangat berkembang pesat, banyak gagasan-gagasan yang kemudian dijadikan sebuah usaha dalam menghadapi perkembangan di jaman modern sekarang ini, contoh kecil dari perkembangan teknologi adalah; pemasukan oksigen di dalam kemasan botol air minum.dan banyak kemajuan teknologi lainnya yang dikembangkan pada era sekarang.

Banyak air minum beroksigen yang sering kita temui di pasaran.produk air beroksigen adalah suatu kemajuan, lahirnya produk air beroksigen disebabkan manusia membutuhkan air minum yang sehat, bukan sekedar menghilangkan dahaga.air memiliki fungsi fisiologis yang sangat penting dalam tubuh,sekitar 70 persen bobot orang dewasa berupa air,jika air yang kita konsumsi berkualitas baik maka kesehatan kita akan meningkat begitu juga jika kita mengkonsumsi air yang buruk maka kesehatan kita menurun.tetapi sebelum munculnya minuman-minuman beroksigen dahulu orang banyak 
mengkonsumsi air mineral dan sekarang lebih banyak orang memilih minuman beroksigen di banding air mineral, Air minum tersebut memiliki beragam manfaat yang menyehatkan. Air minum beroksigen dalam dunia olahraga berperan penting dalam membantu aktifitas fisik olahragawan karena air minum yang mengandung oksigen lebih banyak dibanding dengan air minum pada umumnya, sehingga dapat menambah kadar oksigen dalam darah dan juga dapat meningkatkan ketahanan untuk pemulihan kardio-respirasi. Sehingga bemanfaat bagi tubuh kita terutama yang sehabis beraktifitas.

\section{KAJIAN PUSTAKA}

Minuman Beroksigen. Minuman oksigen berarti minuman yang telah dicampurkan atau memiliki kandungan oksigen yang angat inggi, hasil uji lab menunjukan bahwa kadar oksigen dalam air oksigen mencapai 10 kali lipat kadar oksigen jenuh pada air biasa. Air secara alamiah sudah mengandung oksigen sebanyak 10 ppm (part per million $=10$ miligram per liter). Pada suhu lebih rendah (misalnya dalam lemari pendingin), kadar oksigen dapat meningkat hingga maksimal $15 \mathrm{ppm}$. manfaat air minum beroksigen mencegah terjadinya batu ginjal dan kencing batu, mencegah pengendapan pada empedu, mengurangi racun dalam darah, meningkatkan metabolism dan juga memperingan kerja jantung dan menstabilkan tekanan darah.

Minuman Beroksigen adalah "Air minum Penambah Oksigen yang dibuat secara khusus, dengan tekanan dan suhu tertentu, yang memungkinkan air itu mampu menangkap oksigen lebih banyak, berkat kemajuan teknologi pangan. Oksigen kini tak lagi hanya dapat dihirup, tetapi bisa juga dimasukan mela lui pencernaan, sebagai bagian dari gaya hidup modern, dan kini marak dijual produk air dalam kemasan yang mengandung oksigen, Hal ini diperkuat oleh pendapat dari Dr. Rosdiana Ramli SPOG "minuman beroksigen adalah minuman oksigen dalam air mineral yang produksi 7-40 kali dari air mineral biasa. Bahkan ada yang mengklaim bahwa air yang mereka kemas sudah diproses sedemikian rupa sehingga menimbulkan perubahan pada molekul-molekulnya."

Air mineral. Air mineral yang dimaksud adalah air minum bermerek yang ada dipasaran (aqua). Air mineral yang mengandung mineral atau bahanbahan larut lain yang mengandung rasa atau memberi nilai-nilai terapi, banyak mengandung garam, sulfur dan gas-gas yang larut dalam air ini. air mineral biasanya masih berbuih dan bersumber dari mata air yang berada di alam.do indonesia, bisnis air mineral dimulai pada tahun 1973 dengan merek aqua yang didirikan oleh Tirto Utomo dan Ibnu Sutowo, air ini bukan hanya sekedar pelepas dahaga, air memiliki fungsi yang sangat penting dalam menentukan derajat kesehatan karna sekitar $70 \%$ tubuh kita adalah air dan pengaruhnya terhadap kesehatan cukup besar, apabila air yang kita konsumsi berkualitas buruk maka kesehatan kitapun akan menurun dan begitu juga sebaliknya apabila kita mengkonsumsi air yang baik maka kesehatan kita akan meningkat.

Air mineral adalah hal yang sama sekalisini kata "mineral" digunakan dalam referensi untuk zat padat yang dilarutkan di dalam air seperti yang diambil dari sumber alam seperti mata air,zat-zat dilarutkan terjadi di air karena saat air di tanah itu melakukan kontak dengan bahan mineral dan nonmineral.beberapa dari meraka bahan yang larut dan dilarutkan dalam air. air minum yang sehat menurut Prof. Dr. 
Soekidjo Notoatmodjo adalah air minum yang tidak menyebabkan penyakit, maka air tersebut hendaknya diusahakan memenuhi persyaratanpersyaratan kesehatan, air yang sehat harus mempunyai persyaratan sebagai berikut:

a. Syarat fisik

Persyaratan fisik untuk air minum yang sehat adalah bening (tidak berwarna), tidak berasa, suhu dibawah suhu udara diluarnya. Cara mengenal air yang memenuhi persyaratan fisik ini tidak sukar.

b. Syarat bakteriologis

Air untuk keperluan minum yang sehat harus bebas dari segala bakteri, terutama bakteri patogen. cara untuk mengetahui air terkontaminasi patogen adalah dengan memeriksa sample air tersebut. Bila dari pemeriksaan $100 \mathrm{cc}$ air terdapat kurang dari 4 bakteri E Coli maka air tersebut memenuhi syarat kesehatan

c. Syarat kimia

Air yang sehat harus mengandung zat-zat tertentu dalam jumlah yang tertentu pula. kekurangan atau kelebihan salah satu zat kimia dalam air, akan menyebabkan gangguan fisiologis pada manusia.

\section{METODE}

Metode penelitian yang akan digunakan adalah metode eksperimen. Sugiyono mengartikan eksperimen sebagai metode penelitian yang digunakan untuk mencari pengaruh perlakuan tertentu terhadap yang lain dalam kondisi yang terkendalikan. Bentuk desain penelitian menggunakan One Groups "Pre-Test dan Post-Test Design yaitu pemberian pretest sebelum perlakuan dan post test setelah perlakuan.

Adapun yang menjadi variabel bebas adalah Air Minum Beroksigen dan air mineral, sedangkan yang menjadi variabel terikat adalah kadar oksigen dalam darah pada Team Futsal Siswa SMA Islam Al Maruf Cibubur Jakarta Timur.

\section{Populasi}

Sudjana mengartikan populasi adalah sebagai totalitas semua nilai yang mungkin, hasil menghitung ataupun pengukuran, kuantitatif maupun kualitatif mengenai karakteristik tertentu dari semua anggota kumpulan yang lengkap dan jelas yang ingin di pelajari sifat-sifatnya. Dalam penelitian ini yang menjadi populasi adalah team futsal siswasiswa SMA Islam Al Maruf Cibubur yang berjumlah 15 populasi

\section{Sampel}

Dalam penelitian ini,teknik yang digunakan dalam pengambilan sampel adalah Purposive Sampling, dimana dari populasi yang memenuhi criteria sebagai sampel berjumlah 10 siswa. adapun tahapan kriteria pengambilan sample adalah sebagai berikut :

1. Bersedia mengikuti penelitian.

2. Sehat jasmani (surat keterangan dokter).

3. Berjenis kelamin laki-laki .

4. Aktif dalam kegiatan ekstrakulikuler Futsal SMA Islam al maruf

Kriteria pengambilan sampel gagal apabila:

1. Tidak mencapai batas waktu yang ditentukan yaitu 30 menit.

2. Terjadi cedera pada saat penelitian.

Instrumen Penelitian. Instrumen yang digunakan untuk mengumpulkan data dalam penelitian ini adalah dengan melakukan tes Jogging selama 30 menit dan pengukuran Kadar Oksigen di dalam Darah, pada sampel Siswa Team Futsal SMA Islam al-maruf cibubur. 
Teknik Pengumpulan Data. Teknik pengumpulan data yang akan digunakan dalam penelitian ini adalah dengan Pengecekan variabel-variabel yang terdapat dalam penelitian yang diambil dengan cara tes dan pelaksanaan sebagai berikut :

a. Alat yang digunakan
1) Pakaian olahraga
2) Saturasi Oksigen
3) Air mineral
4) Air Minum beroksigen
5) Alat tulis
6) Kalkulator
7) Stopwatch
8) Lapangan

b. Cara Pengukuran

a) Cara pengukuran dengan air beroksigen

1) Siswa mengenakan pakaian olahraga atau pakaian yang ringan

2) Siswa di cek kadar oksigen dalam darah sebelum melakukan jogging

3) Siswa Lari selama 30 menit.

4) Siswa di berikan minuman beroksigen

5) Siswa di cek kadar oksigen dalam darah setelah di berikan minuman beroksigen

b) Cara Pengukuran dengan air mineral

1) Siswa mengenakan pakaian olahraga atau pakaian yang ringan

2) Siswa di cek kadar oksigen dalam darah sebelum melakukan jogging

3) Siswa Lari selama 30 menit.

4) Siswa di berikan minuman air mineral

5) Siswa di cek kadar oksigen dalam darah setelah di berikan air mineral

Anak-anak ini akan dibagi menjadi 4 kelompok. Pada setiap kelompok terdapat 5 individu. Setiap kelompok akan dicek kadar oksigen normal sebelum melakukan aktifitas fisik.

\section{HASIL DAN PEMBAHASAN}

Deskripsi Data. Deskripsi data pada penelitian ini meliputi nilai tertinggi, nilai terendah, standar deviasi,standar error, distribusi frekuensi, serta histogram dari masing-masing variable,berikut data lengkapnya.

\section{Table 3. Data Kadar Oksigen Sampel}

Sebelum Test Awal atau Jogging

\begin{tabular}{c|l|c|c|c|c} 
No & Name & Umur & $\begin{array}{c}\text { \% } \\
\text { SpO } \\
\mathbf{2}\end{array}$ & $\begin{array}{c}\text { Ket } \\
\text { Sehat } \\
\text { Dokter }\end{array}$ & $\begin{array}{c}\text { Ket } \\
\text { Layak } \\
\text { Sampel }\end{array}$ \\
\hline 1 & $\begin{array}{l}\text { Fajri } \\
\text { nurul }\end{array}$ & 17 & 96 & Sehat & Layak \\
\hline 2 & $\begin{array}{l}\text { Rahad } \\
\text { ian }\end{array}$ & 17 & 95 & Sehat & Layak \\
\hline 3 & Bowo & 17 & 95 & Sehat & Layak \\
\hline 4 & Ara & 16 & 95 & Sehat & Layak \\
\hline 5 & Rizal & 16 & 96 & Sehat & Layak \\
\hline 6 & Fadli & 16 & 97 & Sehat & Layak \\
\hline 7 & Rudi & 17 & 95 & Sehat & Layak \\
\hline 8 & Arie & 16 & 94 & Sehat & Layak \\
\hline 9 & Agung & 16 & 97 & Sehat & Layak \\
\hline 10 & $\begin{array}{l}\text { Ari } \\
\text { anggo } \\
\text { ro }\end{array}$ & 15 & 95 & Sehat & Layak \\
& & & &
\end{tabular}

Sumber: Hasil Penelitian

Tabel 4. Deskripsi Data Kadar Oksigen Dalam Darah Tes Awal

\begin{tabular}{|c|c|c|}
\hline Vaiable & $\begin{array}{c}\text { Air } \\
\text { beroksigen }\end{array}$ & $\begin{array}{c}\text { Air } \\
\text { mineral }\end{array}$ \\
\hline Nilai Tertinggi & 99 & 98 \\
\hline Nilai Terendah & 96 & 94 \\
\hline Rata-Rata & 98 & 96,6 \\
\hline $\begin{array}{c}\text { Standar } \\
\text { Deviasi }\end{array}$ & 1,05 & 1,26 \\
\hline Standar Error & 0,35 & 0,42 \\
\hline
\end{tabular}

1. Dari Hasil Efek Kerja Minuman Beroksigen Terhadap Kadar Oksigen Dalam Darah.

Data yang terkumpul mengenai pengaruh minuman beroksigen terhadap 
kadar oksigen dalam darah pada test awal menunjukan rentang nilai terendah 96\% $\mathrm{SpO}_{2}$ sampai dengan nilai tertinggi $99 \% \quad \mathrm{SpO}_{2}$ di dapat rata-rata kadar oksigen dalam darah sebesar $98 \% \mathrm{SpO}_{2}$ untuk standar deviasi sebesar 1,05\% $\mathrm{SpO}_{2}$. Hal tersebut bisa dilihat dalam distribusi frekuensi dan histogram dibawah ini:

Tabel 5. Distribusi Frekuensi Test Kadar Oksigen dalam Darah Awal

\begin{tabular}{|c|c|c|c|c|}
\hline No & $\begin{array}{c}\text { Interval } \\
\text { Kelas }\end{array}$ & $\begin{array}{c}\text { Titik } \\
\text { Tengah }\end{array}$ & Frekuensi & $\%$ \\
\hline 1 & $96-97$ & 96,5 & 3 & $30 \%$ \\
\hline 2 & $98-99$ & 98,5 & 7 & $70 \%$ \\
\hline \multicolumn{3}{|c|}{ jumlah } & 10 & $100 \%$ \\
\hline
\end{tabular}

Data terkumpul diatas menunjukan bahwa dari 10 sampel yang ada, terdapat 3 orang yang memiliki kadar oksigen di dalam darah antara 96 - $97 \% \mathrm{SpO}_{2}$, lalu ada 7 orang yang memiliki kadar oksigen di dalam darah antara $98-99 \% \mathrm{SpO}_{2}$,

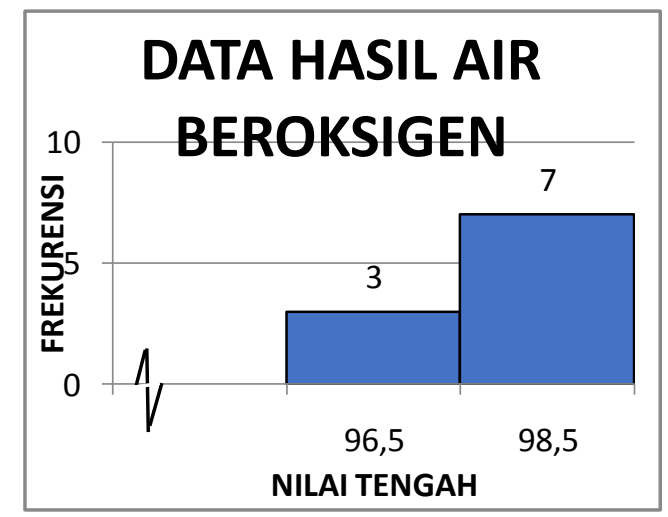

Gambar 6. Grafik Histogram Kadar Oksigen Dalam Darah pada air minum beroksigen

2. Data Hasil Efek Minuman air mineral Terhadap Kadar Oksigen Dalam Darah Akhir

Data akhir yang terkumpul mengenai pengaruh efek kerja minuman beroksigen terhadap kadar oksigen dalam darah test akhir menunjukan rentang nilai terendah $94 \% \mathrm{SpO}_{2}$ sampai dengan nilai tertinggi yaitu memiliki nilai kadar oksigen dalam darah $98 \%$ $\mathrm{SpO}_{2}$. Di dapat rata-rata kadar oksigen dalam darah sebesar $96,6 \% \mathrm{SpO}_{2}$ untuk standar deviasi sebesar $1,26 \% \mathrm{SpO}_{2}$.

Hal tersebut bisa dilihat dalam distribusi frekuensi dan histogram dibawah ini:

\section{Tabel 5. Distribusi Frekuensi Test Kadar Oksigen Dalam Darah Pada Air Mineral}

\begin{tabular}{|c|c|c|c|c|}
\hline No & $\begin{array}{c}\text { Interval } \\
\text { Kelas }\end{array}$ & $\begin{array}{c}\text { Titik } \\
\text { Tengah }\end{array}$ & Frekuensi & $\%$ \\
\hline 1 & $94-95$ & 94,5 & 2 & $20 \%$ \\
\hline 2 & $96-97$ & 96,5 & 6 & $60 \%$ \\
\hline 3 & $98-99$ & 98,5 & 2 & $20 \%$ \\
\hline \multicolumn{3}{|c|}{ Jumlah } & 10 & $100 \%$ \\
\hline
\end{tabular}

Data terkumpul diatas menunjukan bahwa dari 10 sampel yang ada, terdapat 2 orang yang memiliki kadar oksigen di dalam darah antara 94 - $95 \% \mathrm{SpO}_{2}$, lalu ada 6 orang yang memiliki kadar oksigen di dalam darah antara $96-97 \% \quad \mathrm{SpO}_{2}$, kemudian ada orang yang memiliki kadar oksigen di dalam darah antara 98 - $99 \% \mathrm{SpO}_{2}$.

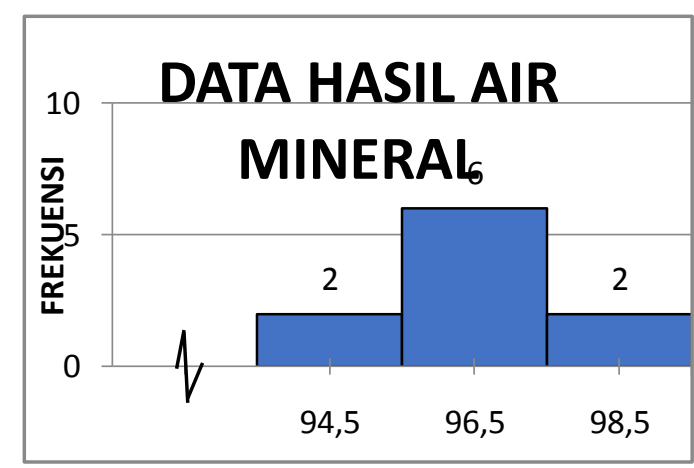

Gambar 7. Grafik Histogram Kadar Oksigen Dalam Darah Akhir pada air mineral

\section{A. Pengujian Hipotesis}

Setelah dilakukan penghitungan maka didapatkan rata-rata pada test air beroksigen sebesar $98 \% \mathrm{SpO}_{2}$ dan pada test pada air mineral di dapatkan rata- 
rata sebesar 96,6\% $\mathrm{SpO}_{2}$. Lalu dari hasil pengujian hipotesis didapatkan hasil.

1. Efek kerja minuman beroksigen terhadap kadar oksigen dalam darah selah melakukan jogging 30 menit jadi Nilai t-tabel dengan derajat kebebasan $(\mathrm{dk}) \mathrm{n}_{1}-1=10-1=9$ Pada taraf kepercayaan $\alpha=0,05$ adalah 2,26. Karena t-hitung $(8,5)>$ t-tabel $(2,26)$ maka $\mathrm{H}_{0}$ diterima Sehingga dapat disimpulkan bahwa terdapat efek kerja minuman beroksigen terhadap saturasi oksigen setelah jogging 30 menit

2. Efek kerja minuman air mineral terhadap kadar oksigen dalam darah setelah melakukan jogging 30 menit Nilai t-tabel dengan derajat kebebasan $(\mathrm{dk}) \mathrm{n}_{1}-1=10-1=9$ Pada taraf kepercayaan $\alpha=0,05$ adalah 2,26. Karena t-hitung $(1)<\mathrm{t}$ tabel $(2,26)$ maka $\mathrm{H}_{0}$ ditolak Sehingga dapat disimpulkan bahwa efek kerja air mineral terhadap jogging 30 menit tidak berpengaruh

3. Perbandingan air minum beroksigen dan air mineral terhadap saturasi oksigen dalam darah setelah melakukan jogging terdapat perbedaan pada hasil test,yang menunjukan air beroksigen lebih signifikan. Karena t-hitung $(2,90)<$ t-tabel $(2,10)$, dengan demikian $\mathrm{H}_{0}$ ditolak, ada perbedaan pengaruh peningkatan kadar oksigen dalam darah pada air minum beroksigen dan air mineral dimana air beroksigen mendapat pengaruh lebih besar terhadap peningkatan kadar oksigen dalam darah dibandingkan dengan air mineral setelah melakukan jogging selama 30 menit.

Maka di ambil keputusan bahwa terdapat penigkatan kadar oksigen dalam darah pada air beroksigen dan air mineral pada kerja jogging setelah meminum minuman beroksigen atau air mineral.

\section{KESIMPULAN DAN SARAN}

Kesimpulan. Berdasarkan penelitian yang dilakukan maka dapat diambil kesimpulan bahwa perbandingan efek kerja minuman beroksigen dan air mineral memiliki pengaruh terhadap kadar oksigen dalam darah, akan tetapi air beroksigen lebih signifikan dibanding air mineral. Lalu dari hasil analisis data di dapatkan bahwa:

1. Efek kerja minuman beroksigen terhadap kadar oksigen dalam darah selah melakukan jogging 30 menit jadi Nilai t-tabel dengan derajat kebebasan $(\mathrm{dk}) \mathrm{n}_{1}-1=10-1=9$ Pada taraf kepercayaan $\alpha=0,05$ adalah 2,26. Karena t-hitung $(8,5)>$ t-tabel $(2,26)$ maka $\mathrm{H}_{0}$ diterima Sehingga dapat disimpulkan bahwa terdapat efek kerja minuman beroksigen terhadap saturasi oksigen setelah jogging 30 menit

2. Efek kerja minuman air mineral terhadap kadar oksigen dalam darah setelah melakukan jogging 30 menit Nilai t-tabel dengan derajat kebebasan $(\mathrm{dk}) \mathrm{n}_{1}-1=10-1=9$ Pada taraf kepercayaan $\alpha=0,05$ adalah 2,26. Karena t-hitung $(1)<\mathrm{t}$ tabel $(2,26)$ maka $\mathrm{H}_{0}$ ditolak Sehingga dapat disimpulkan bahwa efek kerja air mineral terhadap jogging 30 menit tidak berpengaruh.

3. Perbandingan air minum beroksigen dan air mineral terhadap saturasi oksigen dalam darah setelah melakukan jogging terdapat perbedaan pada hasil test,yang menunjukan air beroksigen lebih signifikan. Karena t-hitung $(2,90)<$ t-tabel $(2,10)$, dengan demikian $\mathrm{H}_{0}$ ditolak, ada perbedaan pengaruh peningkatan kadar oksigen dalam darah pada air minum beroksigen dan air mineral dimana air beroksigen mendapat pengaruh lebih besar terhadap peningkatan kadar 
oksigen dalam darah dibandingkan dengan air mineral setelah melakukan jogging selama 30 menit.

Saran. Dari hasil penelitian ini peneliti ingin menyampaikan saran-saran sebagai berikut :

1. Sebaiknya kita harus mengetahui kadar oksigen di dalam darah sebelum melakukan olahraga apapun, dengan kita mengetahui kadar oksigen dalam tubuh kita, kita dapat mengetahui apakah tubuh kita cukup dalam mengkonsumsi oksigen yang akan digunakan ketika berolahraga, terutama ke dalam olahraga yang menggunakan pemakaian oksigen atau aerobik.

2. Untuk yang akan beraktifitas fisik ada baiknya untuk memulihkan kehilangan cairan dan kadar oksigen dalam darah yang terbuang sehabis beraktifitas ada baiknya mengkonsumsi air minum yang memiliki kadar oksigen tidak sekedar air mineral yang kita ketahui juga dapat mengembalikan cairan yang hilang sehabis beraktifitas

3. Bagi yang akan melakukan penelitian yang seragam supaya memperhatikan faktor-faktor yang sangat mempengaruhi hasil penelitian agar memperoleh hasil yang maksimal seperti pengaturan waktu istirahat, lamanya jeda waktu diantara meminum kadar oksigen dalam darah, cuaca serta sampel yang siap untuk melakukan penelitian.

\section{DAFTAR RUJUKAN}

Anas Sudjiono. Pengantar Statistik Pendidikan. Yogyakarta: Andi, 2000.

Arie S Sutopo dan Alma Permana Lestari, Buku Penuntun Praktikum Ilmu Faal Kerja. Jakarta: FIK UNJ, 2002.
Basoeki, Soedjono,Anatomi dan Fisiologi Manusia. Jakarta: Depdikbud, 1988.

Bryan Sharkey. Kebugaran dan kesehatan, Jakarta: PT Raja Grafindo Persada, 2003.

Dangsiana Moeloek Dan Arjotmo Tjokronegoro. Kesehatan dan Olahraga. Jakarta: Fakultas Kedokteran Universitas Indonesia, 1984.

Darmanto Djojodibroto R, Respirologi Penerbit: EGC.

Ganong F. William, Buku Ajar Fisiologi Kedokteran Ed. 22. Terjemahan Andita Novrianti, Jakarta: Penerbit Buku Kedokteran EGC, 2008.

Harsono. Prinsip-Prinsip Pelatihan. Jakarta: Pusat Pendidikan dan Penataran, KONI Pusat,1993,

Johan Schurink dan Sjouck tel, Jogging. terjemahan Soeparno Jakarta: PT Rosda Jayaputra Offset, 1987.

Mohamad, Sadikin, Biokimia darah. Jakarta: Widya Medika, 2001.

Novita Hera Anggraeny, Rancang Bangun Alat Ukur Kadar Haemoglobin, Kandungan Oksigen Dan Kadar Gula Dalam Darah Pada Manusia Secara Non invasive Berbasis Mikro kontroler. Semarang: Universitas Diponogoro Semarang, 2010.

Pearce, Evelyn, Anatomi dan Fisiologi untuk Paramedis. Jakarta: PT. Gramedia, 1979.

Richard L. Brown, dan Joe Henderson, Bugar Dengan Lari.Jakarta: PT Raja Grafindo Persada 1996,

Siregar WD, Air Mineral dan Air Demineral. Universitas Sumatra Utara

Sudjana, Metode Statistika. Bandung: PT.Tarsito, 2005.

Sugiono, Metode Penelitian Kuantitatif, Kualitatif. $\quad$ Bandung: CV Alfabeta,2001, 
Soekidjo Notoatmodjo, Kesehatan Masyarakat Ilmu dan Seni. Jakarta : PT Rineka Cipta, 2007

Syaifuddin, Anatomi dan Fisiologi Manusia. Jakarta: Depdikbud, 1988

S. Nasution, Metodologi Research. Jakarta: bumi Aksara, 2002.

Yudha M. Saputra Dasar Dasar Keterampilan Atletik. Jakarta: Direktorat Jendral Olahraga, Depdiknas, 2001.

http://id.wikipedia.org/wiki/Haemoglobi n. Haemoglobin Diakses tanggal 14 April.

http://id.medicinenet.com, Minuman beroksigen. tanggal 10 Oktober 2014.

http://id.wikipedia.org/wiki/ Air mineral, air mineral. terakhir diakses 18 November 2013

http://.geology.com air mineral. diakses 9 Februari 2011.http://Falahkharisma.blogspot.com. manfaat minuman oksigen, selasa tanggal 6 Desember 2008. 